\title{
COMMENTS
}

\section{The Business Necessity Defense to Disparate-Impact Liability Under Title VII}

In Griggs v. Duke Power Co., ${ }^{1}$ the Supreme Court expanded the scope of possible liability under Title VII of the Civil Rights Act of $1964^{2}$ by holding that employment practices that have a disparate impact on a protected class, although not discriminatory on their face, are unlawful unless justified by "business necessity." 3 The Griggs Court did not, however, discuss the scope of the business

1401 U.S. 424 (1971).

2 Pub. L. No. $88-352, \S \S 701-716,78$ Stat. 352 (codified at 42 U.S.C. $\S \S 2000 \mathrm{e}$ to $2000 \mathrm{e}-$ 15 (1976)) [hereinafter cited as Title VII]. The Act provides in pertinent part:

(a) It shall be an unlawful employment practice for an employer-

(1) to fail or refuse to hire or to discharge any individual, or otherwise to discriminate against any individual with respect to his compensation, terms, conditions, or privileges of employment, because of such individual's race, color, religion, sex, or national origin; or

(2) to limit, segregate, or classify his employees or applicants for employment in any way which would deprive or tend to deprive any individual of employment opportunities or otherwise adversely affect his status as an employee, because of such individual's race, color, religion, sex, or national origin.

42 U.S.C. § $2000 \mathrm{e}-2(\mathrm{a})$.

3 401 U.S. at 431. Title VII prohibits intentional discrimination on the basis of race, color, religion, sex, or national origin as well as disparate impact caused by an employment practice such as that in Griggs. An employer need not be acting out of personal animosity toward a protected class to be guilty of intentional discrimination; it is only necessary that, for whatever reasons, he is using a racial or other prohibited criterion. See, e.g., Phillips v. Martin Marietta Corp., 400 U.S. 542 (1971); Diaz v. Pan Am. World Airways, Inc., 442 F.2d 385 (5th Cir.), cert. denied, 404 U.S. 950 (1971). But see International Bhd. of Teamsters v. United States, 431 U.S. 324, 335 n.15 (1977) ("Proof of discrminatory motive is critical"). See also Fiss, A Theory of Fair Employment Laws, 38 U. CHI. L. REv. 235, $298-99$ (1971).

A narrow exception to this broad ban does exist. Employers may discriminate on the basis of religion, sex, or national origin where the criteria are "bona fide occupational qualification[s]." Title VII, $\S 703(\mathrm{e}), 42$ U.S.C. $\S 2000 \mathrm{e}-2(\mathrm{e})$ (1976). See generally B. SchLEI \& P. Grossman, Employment Discrimination Law 278-92 (1976).

The Act also requires an employer to make reasonable accommodations to an employee's religious observances or practices. This requirement originated in the 1966 EEOC Guidelines on Discrimination Because of Religion, 31 Fed. Reg. 8370 (1966) (current version at 29 C.F.R. $\S 1605.1(b)$ (1978)). Although the requirement was originally thrown in doubt by the courts, see, e.g., Dewey v. Reynolds Metal Co., 429 F.2d 324 (6th Cir. 1970), aff'd mem. by an equally divided court, 402 U.S. 689 (1971), it was ratified by Congress in 1972. Equal Employment Opportunity Act of 1972, Pub. L. No. 92-261, $\S 2(7), 86$ Stat. 103 (codified at 42 U.S.C. \$ 2000e(j) (1976)). See generally TWA v. Hardison, 432 U.S. 63 (1977); B. SchleI \& P. GrossMAN, supra, at 185-219. 
necessity defense. ${ }^{4}$ Consequently, lower courts have been afforded a considerable degree of freedom in shaping the contours of the defense. Although the Supreme Court applied the doctrine rather liberally in one recent case, ${ }^{5}$ most courts have construed the defense narrowly; ${ }^{6}$ many of them have adopted a "balancing" approach, in which the disparate impact of an employer's practice is balanced against the benefits of the practice.

The strict application of the business necessity defense has meant that many legitimate profit-maximizing business practices have triggered Title VII liability. Title VII has thus imposed additional costs on employers by preventing the use of efficient business practices whenever the benefits derived from the practices do not outweigh their adverse impact on a protected class. This subordination of profit-maximizing practices to the goal of enhancing minority employment has been called unsound as a matter of social pol-

- See 401 U.S. at 431 . For the Court to have set forth the scope would have been dictum in any event since the employer conceded that he adopted the standards in question "without meaningful study of their relationship to job-performance ability." Id.

${ }^{5}$ New York City Transit Auth. v. Beazer, 99 S. Ct. 1355, 1366 n.31 (1979), discussed in text at notes $42-44$ infra.

- See, e.g., Blake v. City of Los Angeles, 595 F.2d 1367, 1377 (9th Cir. 1979) (defense is "very narrow"); Green v. Missouri Pac. RR., 523 F.2d 1290, 1298 (8th Cir. 1975) (business necessity " "connotes an irresistible demand" "); United States v. Jacksonville Terminal Co., 451 F.2d 418, 451 (5th Cir. 1971) (same), cert. denied, 406 U.S. 906 (1972); United States v. Bethlehem Steel Corp., 446 F.2d 652, 662 (2d Cir. 1971) (same). See also Note, Business Necessity Under Title VII of the Civil Rights Act of 1964: A No-Alternative Approach, 84 YALE L.J. 98, 101-02 (1974) [hereinafter cited as Yale Note].

7 See, e.g., Townsend v. Nassau County Medical Center, 558 F.2d 117, 120 (2d Cir. 1977), cert. denied, 434 U.S. 1015 (1978); Rodriguez v. East Tex: Motor Freight, 505 F.2d 40, 56-57 (5th Cir. 1974), rev'd on other grounds, 431 U.S. 395 (1977); Hodgson v. Greyhound Lines, Inc., 499 F.2d 859 (7th Cir. 1974), cert. denied; 419 U.S. 1122 (1975); United States v. N.L. Indus., Inc., 479 F.2d 354, 365-66 (8th Cir. 1973); Spurlock v. United Airlines, Inc., 475 F.2d 216, 219 (10th Cir. 1972); Robinson v. Lorillard Corp., 444 F.2d 791, 798 (4th Cir. 1971), cert. dismissed, 404 U.S. 1006 (1972); B. SchLEI \& P. GROssman, supra note 3, at 143-47; Note, Application of the EEOC Guidelines to Employment Test Validation: A Uniform Standard for Both Public and Private Employers, 41 GEo. WASH. L. REv. 505, 521-22 (1973) [hereinafter cited as Note, Application of the EEOC Guidelines to Employment Test Validation]; Note, Fair Employment Practices: The Concept of Business Necessity, 3 MEM. ST. U.L. REv. 76, 83, 88-91 (1972) [hereinafter cited as Note, Fair Employment Practices]; Note, Facially Neutral Criteria and Discrimination Under Title VI: "Built-in Headwinds" or Permissible Practices?, 6 U. Mich. J.L. REF. 97, 109 n.71 (1972) [hereinafter cited as Note, Facially Neutral Criteria and Discrimination Under Title VII]; Yale Note, supra note 6, at 101 \& n.18; 6 GA. L. REv. 194, 201 (1971); Annot., 36 A.L.R. Fed. 9, 25-29 (1978). The Equal Employment Opportunity Commission has incorporated a balancing test in its own regulations. 29 C.F.R. $\S 1607.5$ (c)(2)(iii) (1978). The Ninth Circuit seems to have suggested a balancing standard. See Blake v. City of Los Angeles, 595 F.2d 1367, 1378 (9th Cir. 1979); Johnson v. Pike Corp., 332 F. Supp. 490 (C.D. Cal. 1971). Johnson has been widely criticized. See Wilson, A Second Look at Griggs v. Duke Power Company: Ruminations on Job Testing, Discrimination, and the Role of the Federal Courts, 58 VA. L. REv. 844, 850-51 (1972); 85 HARv. L. REv. 1482 (1972). 
icy. ${ }^{8}$ Still, many have argued that a restrictive application of the business necessity defense is faithful to Congress's intent in enacting Title VII.'

This comment argues, however, that a proper determination of the scope of the business necessity defense should turn on what concept of equality underlies the disparate-impact liability of Griggs-equal, color-blind ${ }^{10}$ treatment of individuals, or equal social and economic achievement for protected classes. Specifically, the comment maintains that although an equal-achievement theory of Title VII can easily be reconciled with the courts' narrow construction of the defense, an equal-treatment rationale necessarily implies that the defense should protect almost all profit-maximizing employment practices. After an analysis of the legislative history and judicial development of Title VII, the comment concludes that the statute's goal is the equal treatment of individuals, not equal achievement for protected classes, and that consequently, the business necessity defense has been applied too restrictively.

\section{The Griggs Decision}

Griggs v. Duke Power Co. was a class action alleging that Duke Power Company was violating Title VII of the Civil Rights Act of 1964 by requiring a high school diploma and satisfactory aptitude test scores as conditions of employment in its upper-level jobs."1 Duke Power was divided into five operating departments; before 1965, blacks were hired only in the labor department, where the highest-paying job paid less than the lowest-paying job in any of the other four departments. Since 1955 Duke Power had required

See generally Fiss, supra note 3, at 257; Tobin, On Improving the Economic Status of the Negro, 94 Daedalus 878 (1965). See also Landes, The Economics of Fair Employment Laws, 76 J. Pol. Econ. 507, 508-13, 545-48 (1968).

- E.g., Blumrosen, Strangers in Paradise: Griggs v. Duke Power Co. and the Concept of Employment Discrimination, 71 MrcH. L. Rev. 59 (1972); Jain \& Ledvinka, Economic Inequality and the Concept of Employment Discrimination, 26 LAB. L.J. 579, 579 (1975) ("economic inequality was what Congress set out to attack with [Title VII]"); Note, Fair Employment Practices, supra note 7.

10 For the sake of textual simplicity, this comment will frequently speak only of discrimination against blacks. Title VII is, of course, not limited to racial discrimination; it also covers discrimination on the basis of sex, religion, or national origin. There are some distinctions in the legal treatment of different bases of discrimination. For example, racial discrimination is not subject to the exception for "bona fide occupational qualification," see note 3 supra. For the most part, however, the different bases of discrimination are analytically interchangeable-what is said of racial discrimination applies equally well to its cognates-and the analysis of this comment applies to Title VII discrimination generally.

"The plaintiffs also contended that Duke Power had discriminated in its allocation of overtime. See note 16 infra. 
a high school education for initial employment in all departments except labor, and for interdepartmental transfers into the three most preferred departments. In 1965, Duke Power dropped its racial restrictions on hiring, but required all applicants for nonlabor jobs to pass two professionally prepared aptitude tests. ${ }^{12}$

The hiring criteria-aptitude tests and high school diplomaoperated to exclude blacks proportionately more than whites, ${ }^{13}$ and showed no "demonstrable relationship to successful performance of the jobs for which ... . [they were] used."14 There was no indication, however, that the requirements had been instituted with a discriminatory motive. ${ }^{15}$

Duke Power's black employees, suing for themselves and for a class including future black employees, challenged the education and testing requirements, contending that the criteria operated to perpetuate the effects of past discriminatory practices. ${ }^{16}$ And specifically with respect to the permissibility of the tests, the plaintiffs relied ${ }^{17}$ on an Equal Employment Opportunity Commission (EEOC) decision ${ }^{18}$ interpreting section $703(\mathrm{~h})$ of Title VII ${ }^{19}$ as re-

12 This change went into effect on July 2, 1965, the effective date of Title VII. Griggs v. Duke Power Co., 401 U.S. 424, 427 (1971). Two months later, Duke Power agreed to allow previously hired personnel to apply for interdepartmental transfers with either a high school diploma or a passing grade on the two tests. Id. at 427-28.

13 Whites had a significantly higher pass rate on the tests than blacks, and completion of high school was far more prevalent among whites than blacks. See Griggs v. Duke Power Co., 420 F.2d 1225, 1239 n.6 (4th Cir. 1970), rev'd, 401 U.S. 424 (1971). Both of these tendencies were considered to be directly traceable to the inferior education afforded blacks in North Carolina's segregated schools. Id.

is 401 U.S. at 431.

is Id. at 432.

" Griggs v. Duke Power Co., 420 F.2d 1225, 1229 (4th Cir. 1970), rev'd, 401 U.S. 424 (1971). The plaintiffs argued that Duke Power discriminated in three different ways: (1) placement of the plaintiffs "in the low paying labor department and ... . [denial of] access to the more desirable departments as a result of the defendant's discriminatory hiring and promotional policies," Griggs v. Duke Power Co., 292 F. Supp. 243 (M.D.N.C. 1968), aff'd in part, rev'd in part, 420 F.2d 1225 (4th Cir. 1970), rev'd, 401 U.S. 424 (1971); (2) "allowing passing marks on two general intelligence tests to substitute for a high school education in determining eligibility for departmental transfer," id. at 249; and (3) "allocation of overtime work at its Dan River Station," id. at 250.

${ }^{17}$ See Griggs v. Duke Power Co., 420 F.2d 1225, 1233-34 (4th Cir. 1970), rev'd, 401 U.S. 424 (1971).

is Decision of EEOC (Dec. 2, 1966) (published in EMPL. Prac. Guide (CCH) ๆ 17,304.53) (cited by the Fourth Circuit, 420 F.2d at 1223, and by the Supreme Court, 401 U.S. at 430 n.6).

1942 U.S.C. $\$ 2000 \mathrm{e}-2(\mathrm{~h})$ (1976). The section provides in part:

Notwithstanding any other provision of this subchapter, it shall not be an unlawful employment practice . . . for an employer to give and to act upon the results of any professionally developed ability test provided that such test, its administration or action 
quiring that any standardized tests be shown to be job related.

The district court dismissed the complaint. ${ }^{20}$ It held that Title VII has no retroactive force and thus provides no remedy for discrimination occurring before $1965 .{ }^{21}$ The court also rejected the EEOC's interpretation of section 703(h), holding that the Act does not "require that employers . . . utilize only those tests which accurately measure the ability and skills required of a particular job or group of jobs." 22 Moreover, according to the court, the high school education requirement did not violate Title VII since it had "a legitimate business purpose and [was] equally applicable to both Negro and white employees similarly situated." ${ }^{23}$

The Fourth Circuit, in an opinion by Judge Boreman, reversed the lower court decision in part. ${ }^{24}$ The court concluded that Title VII does allow the courts to remedy prospectively the present effects of prior discrimination, ${ }^{25}$ but agreed with the trial court that neither section 703(h) nor Title VII required Duke Power to show a specific relation between its hiring criteria and particular jobs. ${ }^{28}$

The Supreme Court granted certiorari ${ }^{27}$ on the question whether Title VII prohibits facially neutral employment criteria that exclude a disproportionately high number of blacks when those criteria are not "shown to be significantly related to successful job performance." 28 In reversing the lower court rulings, the Court established a new rule of Title VII liability. The Court held that Title VII reaches not only intentional discrimination, but also employment practices that are neutral on their face and in their intent, yet which have the effect of excluding minority applicants. ${ }^{29}$ The Act, the Court held, forbids "practices that are fair in form, but discriminatory in operation. The touchstone is business necessity. If an employment practice which operates to exclude Negroes can-

upon the results is not designed, intended or used to discriminate because of race, color, religion, sex or national origin.

292 F. Supp. at 252.

${ }^{21} \mathrm{Id}$. at 247.

22 Id. at 250 .

25 Id. at 251 .

24 420 F.2d at 1237.

${ }^{25}$ Id. at 1230-31. On this ground, the court held that the testing and high school diploma requirements could not be applied to six plaintiff-employees hired before 1955 . When they were hired, there was no diploma or testing requirement; hence, they had been limited to the labor department solely because of Duke Power's racial restrictions.

2s Id. at 1234-35. Judge Sobeloff dissented from this position of the majority. Id. at 123944 (Sobeloff, J., concurring in part, dissenting in part).

${ }^{27}$ Griggs v. Duke Power Co., 399 U.S. 926 (1970).

23 Griggs v. Duke Power Co., 401 U.S. 424, 426 (1971).

Id. at $430-32$. 
not be shown to be related to job performance, the practice is prohibited." ${ }^{30}$ Chief Justice Burger, writing for the Court, stressed that Congress, in enacting Title VII, was concerned with "the consequences of employment practices, not simply the motivation," 31 and that the employer had the burden of showing that its hiring criteria were related to the specific jobs to which those criteria applied. ${ }^{32}$

The Court held that Duke Power's testing and education requirements violated Title VII, since Duke Power had not contended that the criteria were related to the demands of any particular job or class of jobs, and since it had failed to show that the criteria helped to assure that entering employees would later be qualified for advancement to higher levels under Duke Power's promotion system..$^{33}$ Chief Justice Burger went on to reject Duke Power's argument that section 703(h) made lawful the use of its professionally developed tests; Congress, the Chief Justice concluded, meant to protect only job-related tests. ${ }^{34}$

The Court's holding and its very general statements concerning the business necessity defense left open at least three critical questions regarding the defense. First, the Court did not identify what sorts of business purposes should justify an employer's practices under the business necessity defense. This issue was settled easily in subsequent lower court cases. The typical formulation of the rule is that a legitimate business purpose is one essential to the safe and efficient operation of the business.$^{35}$ Hence, conformity with industry practice or the preservation of the status quo, for example, are not sufficient justifications. ${ }^{36}$ Lower courts have also held that an employer may not use otherwise illegal practices to accommodate

${ }^{30}$ Id. at 431 .

${ }^{31}$ Id. at 432 (emphasis in original).

32 Id.

${ }^{33}$ Id. at 431-32. The Court thus left open the question whether an entry-level criterion may properly test for capacity for future in-house promotion. Id. at 432 .

is Id. at 433-36.

${ }^{35}$ E.g., Rock v. Norfolk \& W. Ry., 473 F.2d 1344, 1349 (4th Cir.), cert. denied, 412 U.S. 933 (1973); United States v. St. Louis-S.F. Ry., 464 F.2d 301, 308 (8th Cir. 1972) (en banc), cert. denied, 409 U.S. 1116 (1973); United States v. Bethlehem Steel Corp., 446 F.2d 652, 662 (2d Cir. 1971); Robinson v. Lorillard Corp., 444 F.2d 791, 798 (4th Cir.), cert. dismissed, 404 U.S. 1006 (1971). But see Johnson v. Pike Corp., 332 F. Supp. 490, 495 (C.D. Cal. 1971).

so Robinson v. Lorillard Corp., 444 F.2d 791, 798-99 (4th Cir.), cert. dismissed, 404 U.S. 1006 (1971); United States v. City of Chicago, 411 F. Supp. 218, 235 (N.D. Ill. 1976), rev'd in part on other grounds, 549 F.2d 415 (7th Cir.), cert. denied, 434 U.S. 875 (1977). 
discriminatory preferences of consumers ${ }^{37}$ or workers. ${ }^{38}$

Second, the Court did not address what the quantum and nature of proof should be for showing the nexus between the employer's business purpose and the means employed for achieving that purpose. The result has been a series of complicated Supreme Court decisions focusing largely on the problems concerning the validation of testing requirements. The problem has not been entirely resolved, but an analysis of the Court's attempts to resolve it is beyond the scope of this comment. ${ }^{39}$

Finally, the Court did not discuss how "necessary" the business purpose must be in order to establish the defense. One possible interpretation involves requiring an employer to show only that the practice serves a legitimate business purpose. Another possibility is that the Court intended a balancing test comparing the benefit to the employer with the adverse impact on minority applicants. How the defense is to be applied depends on whether, and to what extent, Title VII was intended to impose positive costs on employers who are innocent of intentional discrimination. ${ }^{40}$ If a legitimate business purpose is in itself a complete defense, then no employer would be required to incur any substantial expense to comply with Title VII. The Act would then merely operate to prevent employers from using devices that discriminate (intentionally or not) against minorities and that serve no legitimate function. By contrast, if the defense involves a balancing test, then an employer may sometimes be found liable under Title VII for using an employment practice that fosters a legitimate purpose in the operation of his business. Under this approach, Title VII would force the employer to absorb a cost-what he would have saved by using the prohibited practice-and thus prevent him from behaving as a rational, profitmaximizing businessman.

${ }^{37}$ Diaz v. Pan Am. World Airways, Inc., 442 F.2d 385, 389 (5th Cir.), cert. denied, 404 U.S. 950 (1971). See also EEOC Guidelines on Discrimination Because of Sex, 29 C.F.R. $\S$ 1604.2(a)(1)(iii) (1978). (1971).

${ }^{38}$ Ropinson v. Lorillard Corp., 444 F.2d 791, 799 (4th Cir.), cert. dismissed, 404 U.S. 1006

3" See generally Bernhardt, Griggs v. Duke Power Co.: The Implications for Private and Public Employers, 50 Tex. L. REv. 901 (1972); Shoben, Probing the Discriminatory Effects of Employee Selection Procedures with Disparate Impact Analysis Under Title VII, 56 TEx. L. REv. 1 (1977); Wilson, supra note 7; Note, Application of the EEOC Guidelines to Employment Test Validation, supra note 7; Note, Beyond the Prima Facie Case in Employment Discrimination Law: Statistical Proof and Rebuttal, 89 HARv. L. REv. 387 (1975); Note, Employment Discrimination: Statistics and Preferences Under Title VII, 59 VA. L. REv. 463 (1973).

to See Yale Note, supra note 6, at 99, 102. 
II. Subsequent Judicial Development of the Business Necessity DEFENSE

The federal district courts and courts of appeals have almost uniformly held that the business necessity defense of Griggs is not satisfied simply by a showing that an employment practice serves a legitimate business purpose. ${ }^{41}$ Their holdings may, however, be in conflict with the Supreme Court's construction of the defense in New York City Transit Authority v. Beazer. ${ }^{42}$ In Beazer, the New York City Transit Authority refused to hire methadone users for any position. The plaintiffs, alleging that the defendant's exclusion had a disparate impact on blacks and Hispanics, conceded that goals of safety and efficiency required the exclusion of all methadone users from "safety sensitive" jobs, and of a majority of users from all jobs.43 "[T] hose goals," the Court said, "are significantly served by-even if they do not require-[the defendant's] rule as it applies to all methadone users including those who are seeking employment in nonsafety sensitive positions. . . . The record thus demonstrates that [the defendant's] rule bears a 'manifest relationship to the employment in question," $"{ }_{44}$ as required by Griggs. Thus, the Court held that, even assuming the plaintiffs' statistics made out a prima facie case of disparate impact, the showing of jobrelatedness protected the defendant from liability under Title VII. But while the Beazer Court seemed to apply a lenient standard of business necessity, it did not make explicit the parameters of the defense; hence, it remains unclear whether the lower courts will follow this lead.

Typical of the lower court interpretations is the statement of the rule in Robinson $v$. Lorillard Corp.: $:^{45}$

[T] he applicable test is not merely whether there exists a business purpose for adhering to a challenged practice. The test is whether there exists an overriding legitimate business purpose such that the practice is necessary to the safe and efficient operation of the business. Thus, the business purpose must be sufficiently compelling to override any racial impact; the challenged practice must effectively carry out the business purpose it is alleged to serve; and there must be available no acceptable

" E.g., United States v. N.L. Indus., Inc., 479 F.2d 354, 364-66 (8th Cir. 1973); United States v. Bethlehem Steel Corp., 446 F.2d 652, 662 (2d Cir. 1971); Annot., 36 A.L.R. Fed. 9 (1978).

1299 S. Ct. 1355 (1979).

13 Id. at 1366 n. 31 .

"Id. (alternative ground) (quoting Griggs, 401 U.S. at 432).

ts 444 F.2d 791 (4th Cir.), cert. dismissed, 404 U.S. 1006 (1971). 
alternative policies or practices which would better accomplish the business purpose advanced, or accomplish it equally well with a lesser differential racial impact. ${ }^{46}$

Other courts' formulations of the defense have been similar. In particular, courts have put stress on the word "necessity": "Necessity connotes an irresistible demand. . . . [A practice] must not only directly foster safety and efficiency of a plant, but also be essential to those goals." 47

Under these rules, however formulated, there are a number of ways in which an employment practice that legitimately fosters a business purpose might nonetheless fail to establish the business necessity defense. The clearest, and most important, is the first leg of Robinson's three-part test: the business purpose must be "sufficiently compelling to override any racial impact." In practice, this establishes a balancing test: the greater its disparate impact on minorities, the greater the level of necessity required to justify a practice as a business measure. In a substantial number of cases, such a test will "balance away" what would otherwise be correct, profit-maximizing business actions; indeed, where disparate impact is large, employers will be called upon to make sizable sacrifices in the name of racial equality. ${ }^{49}$

A strict "necessity" requirement-often applied by the courts-does not yield the same sliding scale of justification as the balancing test; rather, it appears to set a floor level of business necessity below which no disparate impact will be excused. The courts have not settled on any more definite formulation of the

" Id. at 798 (footnotes omitted). Accord, Rodriguez v. East Tex. Motor Freight, 505 F.2d 40 (5th Cir. 1974), vacated on other grounds, 431 U.S. 395 (1977); Pettway v. American Cast Iron Pipe Co., 494 F.2d 211, 245-47 (5th Cir. 1974); United States v. N.L. Indus., Inc., 479 F.2d 354, 364-66 (8th Cir. 1973); United States v. St. Louis-S.F. Ry., 464 F.2d 301, 308-09 (8th Cir. 1972) (en banc), cert. denied, 409 U.S. 1116 (1973).

17 United States v. Bethlehem Steel Corp., 446 F.2d 652, 662 (2d Cir. 1971) (citation omitted). Accord, Green v. Missouri Pac. R.R., 523 F.2d 1290, 1295-98 (8th Cir. 1975); United States v. Jacksonville Terminal Co., 451 F.2d 418, 451 (5th Cir. 1971), cert. denied, 406 U.S. 906 (1972). See also Yale Note, supra note 6, at 99-102 (1974).

${ }^{48} 444$ F.2d at 798. But cf. Spurlock v. United Airlines, Inc., 475 F.2d 216 (10th Cir. 1972) (including as factor in balancing test the public's interest in having adequately educated airline pilots).

12 This can lead to anomalous results. Suppose for example, that two employers wish to test applicants for high school level reading ability. Employer $A$ is located in an area with a history of inferior public education for blacks; Employer $B$ is located in an area where the quality of education, whether high or low, received by the two races is more equal (albeit still unequal). If both firms show the same degree of business need for literacy, Employer $B$ might be permitted to use the criterion forbidden to Employer A. See Note, Fair Employment Practices, supra note 7 , at 89. 
precise level of necessity required, ${ }^{50}$ but they have made it clear that mere profit maximization is not sufficient to establish the defense.

It is not clear what is intended by the requirement that there be no available alternative with a less differential impact. The noalternative leg of the Robinson test simply requires that there be no more benign criterion that is as good or better for the employer's purposes. ${ }^{51}$ Such a rule does not impose any costs on employers; it merely posits that a practice is not "necessary" when it can be replaced with another practice without loss. Other cases, however, speak of "reasonably available alternative[s]." 52 That formulation suggests something closer to a balancing approach: an alternative is unreasonable only if its cost is excessive when compared to the improvement in racial balance it will yield..$^{53}$

The Robinson court's interpretation of the business necessity defense has become the conventional one among lower courts, ${ }^{54}$ although the language in which other courts have formulated the defense has sometimes differed. ${ }^{55}$ The formulations of the lower courts, often phrased in terms of "balancing," "strict necessity," or "no reasonably available alternative," or combinations thereof, consistently demonstrate an extremely restrictive application of the business necessity defense. Under any of the formulations, only the most essential business practices will survive attack. The propriety of so restrictively applying the business necessity defense can be evaluated, however, only by taking a closer look at the theoretical foundations of the defense.

${ }^{50}$ See, e.g., United States v. N.L. Indus., Inc., 479 F.2d 354, 365 (8th Cir. 1973) ("compelling business necessity") (citation omitted); United States v. Jacksonville Terminal Co., 451 F.2d 418, 451 (5th Cir. 1971) ("the only feasible or practical modus operandi"), cert. denied, 406 U.S. 906 (1972); United States v. Bethlehem Steel Corp., 446 F.2d 652, 662 (2d Cir. 1971) ("irresistible demand . . . essential to . . . safety and efficiency").

${ }^{51} 444$ F.2d at 798. Accord, e.g., Rodriguez v. East Tex. Motor Freight, 505 F.2d 40, 57 (5th Cir. 1974), vacated on other grounds, 431 U.S. 395 (1977); United States v. St. LouisS.F. Ry., 464 F.2d 301, 308 (8th Cir. 1972) (en banc), cert. denied, 409 U.S. 1116 (1973).

${ }_{52}$ United States v. Bethlehem Steel Corp., 446 F.2d at 662. Accord, Sagers v. Yellow Freight Sys., Inc., 388 F. Supp. 507, 522 (N.D. Ga. 1973); United States v. Local 638, Enterprise Ass'n of Steamfitters, 360 F. Supp. 979, 991 (S.D.N.Y. 1973), aff'd on other grounds, 501 F.2d 622 (2d Cir. 1974).

${ }^{3}$ See also EEOC Dec. No. 72-0708, 4 Fair Empl. Prac. Cas. 437, 438 (1971) (level of reasonable expense an employer must incur in adopting alternatives is directly proportional to the severity and disparity of the impact).

st E.g., Blake v. City of Los Angeles, 595 F.2d 1367, 1376 (9th Cir. 1979); Patterson v. American Tobacco Co., 535 F.2d 257, 265 (4th Cir.), cert. denied, 429 U.S. 920 (1976); Pettway v. American Cast Iron Pipe Co., 494 F.2d 211, 245 (5th Cir. 1974); Head v. Timken Roller Bearing Co., 486 F.2d 870, 879 (6th Cir. 1973).

ss See Annot., 36 A.L.R. Fed. 9, 37-44 (1978). 


\section{The Theoretical Underpinnings of Griggs and the Business NeCESSITY DEFENSE}

There are two major theories of equality currently employed in the interpretation of fair employment laws. ${ }^{58}$ The first is the concept of equal treatment-a doctrine of color-blindness under which all persons are to be treated by employers without regard to their race. This concept is basically an individualistic one, directed toward freeing job competitors from the handicap of racial prejudice. The second concept-equal achievement-focuses instead on the situation and progress of groups. Equality of treatment for individuals, according to equal-achievement theorists, is a spurious sort of fairness because blacks remain hobbled by the disabling effects of centuries of past discrimination; despite the illusion of fair treatment, most blacks are still relegated to a condition of economic and social subordination. Equal achievement thus envisions a redistribution of jobs to improve the employment opportunities of blacks as a class. ${ }^{57}$ Either interpretation of equality-equal achievement or equal treatment-may arguably underlie Griggs. The two interpretations, however, imply greatly different consequences for the scope of the business necessity defense.

\section{A. Equal Achievement}

A ready explanation of Griggs is that it is an acceptance of the equal-achievement concept of discrimination and equality for interpreting Title VII. ${ }^{58}$ Professor Blumrosen states Griggs's holding accordingly: "[D]iscrimination is conduct which has an adverse effect on minority employees as a class." 59

Such an interpretation of Griggs comports with the facts and result of the case. If equal achievement is the ultimate goal of Title

st See generally J. Gardner, ExcELLENCE: CAN We Be EqUal and ExCELlent Too? 11-20 (1961); A. OKun, Equality and Efriciency: The Big Tradeopr 65-87 (1975); Fiss, supra note 3, at 237-38; Nagel, Equal Treatment and Compensatory Discrimination, 2 PHLosophy \& PuB. Afr. 348 (1973). See also Brest, The Supreme Court, 1975 Term-Foreword: In Defense of the Antidiscrimination Principle, 90 HARv. L. REv. 1 (1976); Winter, Improving the Economic Status of Negroes Through Laws Against Discrimination, 34 U. CHI. L. Rev. 817 (1967).

${ }^{37}$ See generally Regents of the Univ. of Cal. v. Bakke, 438 U.S. 265, 387 (1978) (opinion of Marshall, J.); Blumrosen, supra note 9, at 66-74; Fiss, supra note 3, at 237-38, 244-49.

${ }^{\text {ss }}$ It is not a minor point that Griggs was solely a Title VII decision. The case did not purport to lay down a rule for antidiscrimination law generally. See also Blumrosen, supra note 9, at 63. Thus, the Court has since rejected an attempt to apply Griggs's disparateimpact rule to constitutional violations. Washington v. Davis, 426 U.S. 229 (1976) (holding that a claim under the equal protection clause, U.S. CoNST. amend. XIV, $\S 1$, requires a showing of discriminatory intent). See generally Brest, supra note 56, at 22-53.

3) Blumrosen, supra note 9, at 84-85. See id. at 62-63, 67-85. 
VII, then it is improper to limit liability to cases in which discriminatory intent can be proven. Even "color-blind" employment practices have the effect of continuing the economic and social subordination of minority groups whenever the practices have a harsher impact on them than on whites. The requirements at issue in Griggs, in fact, are textbook examples: the diploma and testing requirements, although adopted with no racial motive, had the effect of confining blacks to the lowest-paying jobs. The appropriate standard is consequently not one of intentional discrimination, but one of disparate impact. As Griggs holds, once a plaintiff has shown that a hiring practice operates to exclude blacks at a higher rate than whites, his prima facie case has been made, and it is for the employer to attempt to justify his actions through the business necessity defense. ${ }^{60}$

The equal-achievement characterization of Griggs does not compel any particular rule for the business necessity defense. Viewed by itself, the goal of equal achievement is potentially limitless in terms of the duties and costs that it might impose on employers. If a business necessity defense is interposed as a limit on the means used to pursue that goal, it is not because equal achievement itself requires it; rather, the defense is created to protect other, competing goals such as economic efficiency and entrepreneurial freedom. The degree of protection that the defense provides to employers depends ultimately on the weight given to the competing goals-a legislative value judgment. ${ }^{61}$ For example, if achievement of economic equality is given a very high priority, then the business necessity defense would legitimate only the most compelling and unavoidable employment practices. Conversely, if efficiency and independence of business judgment are valued more highly than equal achievement for racial groups, almost any showing of a legitimate business purpose would provide a complete defense. A myriad of intermediate solutions can be imagined based on different balances between the two goals. Thus, an acceptance of the equalachievement interpretation of Griggs makes the inquiry into the proper scope of the business necessity defense turn on congressional intent: one must determine the priority Congress sought to place on each of the competing policies.

s0 401 U.S. at $430-32$.

1 See generally A. OKun, supra note 56, at 1-5 \& passim. 


\section{B. Equal Treatment}

1. Explaining Griggs in Terms of Functional Equivalence of Race. An alternative explanation for the Court's disparate-impact rule in Griggs can be constructed from a theory of equality and discrimination offered by Professor Fiss. ${ }^{62} \mathrm{He}$ argues that race is an unfair and therefore objectionable employment criterion for two reasons: it is not viewed as an accurate predictor of merit and it is beyond the individual's control. ${ }^{63}$ According to Fiss, "Fair employment laws reflect not only a commitment to the merit principle but also a commitment to the principle that it is desirable to judge individuals on the basis of criteria that are within his [sic] reach."

Fiss argues that a "psychological approach," based solely on the employer's subjective intent, is inadequate for identifying actionable racial discrimination. ${ }^{65}$ There are practical difficulties in proving or disproving a state of mind. Moreover, such a test misses the point of antidiscrimination provisions: the thing forbidden is the use of a racial criterion, not the subjective reason for its use. ${ }^{66} \mathrm{In}$ stead, Fiss would use a two-step inquiry not unlike the rule of Griggs: (1) whether the criterion in fact has an adverse differential impact on blacks; and (2) if so, whether it is unrelated to productivity and beyond individual control. ${ }^{.7}$ If both questions are answered in the affirmative, then, in Fiss's view, the criterion is the functional equivalent of a racial criterion. ${ }^{68}$ Such a criterion shares the same objectionable characteristics as race itself: unrelatedness to merit and lack of individual control.

2. Functional Equivalence as an Equal-Treatment Theory. Although the functional-equivalence theory looks first to the impact of an employment practice on a class as a whole, its true focus is not on the results of an employment practice (as in the equalachievement theory) but on its fairness (as in the equal-treatment theory). The reasoning is thus: if an applicant fails to meet some

2 Fiss, supra note 3.

"Id. at 241.

" Id.

is Id. at 298.

"Id. at 297-99. See also Brest, supra note 56, at 29.

"Fiss, supra note 3, at 299. Similarly, Griggs considers the plaintiff's prima facie case made out by a showing of disparate impact, and then looks to the defendant to show a business justification. 401 U.S. at 432 . But see New York City Transit Auth. v. Beazer, 99 S. Ct. 1355, $1366 \mathrm{n} .31$ (1979). It is not clear, however, how Fiss meant to allocate the burden with regard to his second inquiry-whether job-relatedness is a defense, or whether lack of job-relatedness is part of the plaintiff's burden.

s Fiss, supra note 3, at 299. 
hiring criterion, if the reason for his failure is in some sense related to his membership in a protected group, ${ }^{69}$ and if the criterion serves no legitimate purpose in the employer's business, then disqualifying the applicant on the basis of that criterion is as unfair as disqualifying him directly on the basis of his membership in the protected group. The functional-equivalence analysis is therefore properly characterized as an equal-treatment theory.

The logical advance Fiss makes on the traditional equaltreatment theory is that, in addition to looking at criteria that necessarily do affect any given minority applicant unfairly, he also looks at criteria that are likely to do so. Like the equal-achievement concept, the functional-equivalence theory of discrimination relies heavily on statistics or similar evidence of the actual disparate impact of a hiring criterion on minority groups. This evidence, however, plays a fundamentally different role in the two theories. In the equal-achievement analysis, impact statistics go to the heart of the problem: disparate impact on a class level is itself the evil to be remedied. Fiss's theory, by contrast, places the emphasis on the fairness of a criterion as it applies to individual applicants. A showing of class statistics is relevant, not for its own sake, but because it is generally the best available evidence of the unfairness or bias of the criterion.

3. The Implications of Equal Treatment for the Business Necessity Defense. This interpretation of Griggs effectively dictates its own terms for the scope of the business necessity defense. Business necessity here is not an extraneous, competing policy consideration, as it is under the equal-achievement theory; it is an integral part of the functional-equivalence concept. In Fiss's analysis, it is not unfair to use a criterion that serves a legitimate business purpose, even though the criterion has a disproportionately harsher impact on minority members. It becomes unfair only if that criterion is unrelated to efficiency and productivity; only in

69 Fiss casts this related-to-race aspect of his theory in terms of the individual's lack of control over, or responsibility for, his failure to meet the criterion; it is, he recognizes, essential to his conclusion that such a criterion is unfair, $i d$. at 302-03. The primary source of racerelated incapacity, he suggests, is the lingering effect of past discrimination. For example, a poor public education system may be responsible for blacks' poor performance on a standardized test. Id. at 303. On this point, Fiss anticipated the Griggs Court's point that the disparate impact of Duke Power's criteria was "directly traceable to race" by way of segregated education, 401 U.S. at 430 . See generally Brest, supra note 56, at 31-34. Alternatively, disparate impact could result from simple physical factors. For example, a height requirement has a disparate impact on women, Dothard v. Rawlinson, 433 U.S. 321, 328-31 (1977), or Chicanos, Davis v. County of Los Angeles, 566 F.2d 1334, 1341-42 (9th Cir. 1977), vacated as moot, 99 S. Ct. 1379 (1979). 
such a situation is the criterion as unjustified as the criterion of race. Thus, a showing that an employment practice fosters a legitimate business purpose is virtually a complete defense to Griggs liability, not because the value of the entrepreneurial independence outweighs the discriminatory impact, but because such an employment practice does not constitute discrimination.

In a few special situations, however, a showing by an employer that an employment practice is a profit-maximizing one may fail to establish an adequate business necessity. ${ }^{70}$ First, some employment practices-for example, catering to the bigoted tastes of customers or present employees-might be adopted solely as effective profitmaximizing devices; yet few would hesitate to label them as discriminatory. ${ }^{71}$ In addition, the functional-equivalence theory does not rule out consideration of reasonable alternatives open to the employer. ${ }^{72}$ Suppose, for example, that a job requires knowledge of a certain technical field. Two different standardized tests designed to detect such knowledge are available, both costing the same, but one is written in more difficult language that will penalize certain minority groups. Viewed alone, either test seems to foster a legitimate business purpose. Nevertheless, in view of the obvious, costless alternative, the more disadvantaging test cannot be justified as a business necessity. ${ }^{73}$

The two alternative theoretical justifications for Title VII thus seem to compel quite different approaches to the business necessity defense. Acceptance of the equal-achievement interpretation of Title VII would require a determination of the relative values Congress sought to place on the competing policies of racial equality and business efficiency. Equal treatment, on the other hand, would require a business necessity defense that is established by most legitimate profit-maximizing practices. Since the scope of the business necessity defense turns on the particular theory underlying Title VII, it seems essential to conduct a closer examination of the legislative intent in enacting the statute and the reasoning of the Supreme Court in interpreting it.

70 In some cases, a large adverse impact might be associated with so trivial a business advantage that the challenged practice constitutes no real advantage at all. This implies that there might be a de minimis cutoff for the defense.

is See text and notes at notes 37-38 supra. See also Fiss, supra note 3, at 257-63.

12 Fiss, supra note 3, at 301.02 \& 301 n.73 (quoting Cooper \& Sobol, Seniority and Testing Under Fair Employment Laws: A General Approach to Objective Criteria of Hiring and Promotion, 82 HARv. L. Rev. 1598, 1668 (1969)).

${ }^{73}$ This requirement has been adopted by several lower courts in their formulation of the business necessity defense. See text and notes at notes 51-53 supra. 


\section{Congressional Intent in Enacting Tttue VII}

\section{A. The Legislative History}

Since the business necessity defense came into existence upon the Griggs Court's recognition of disparate-impact liability, Congress did not have occasion, in enacting Title VII, to consider the scope and limitations of the defense. It did, however, debate the broader issue that underlies the business necessity defense: whether Title VII is based on an equal-treatment or an equal-achievement concept of discrimination..$^{74}$ The resulting legislative history consistently shows that the supporters of the bill believed that Title VII was directed solely at unequal and unfair treatment of individuals, ${ }^{75}$ and that it was not expected to infringe on legitimate needs of business efficiency and independence. ${ }^{76}$.

The strongest indication that Title VII embodies a rule of equal treatment, rather than one of equal achievement for protected classes, is found in the definition of discrimination offered by Senators Clark and Case, Title VII's Senate floor managers, in an interpretative memorandum: "To discriminate is to make a distinction, to make a difference in treatment or favor . . . ." Th The memorandum continues, emphasizing that "discrimination is prohibited as to ... individuals" and not classes. ${ }^{78}$

"See, e.g., 110 CoNG. REc. 1518 (1964) (remarks of Rep. Celler); id. at 1540 (remarks of Rep. Lindsay); id. at 1600 (remarks of Rep. Minish); id. at 2557-58 (remarks of Rep. Goodell); id. at 5092, 5094; 5423, 6549 (remarks of Sen. Humphrey); id. at 6564 (remarks of Sen. Kuchel); id. at 7207 (Justice Dept. memorandum introduced by Sen. Clark); id. at 7213 (memorandum of Sens. Clark and Case); id. at 12,617 (remarks of Sen. Muskie). See also United Steelworkers v. Weber, 99 S. Ct. 2721, 2741-53 (Rehnquist, J., dissenting).

${ }^{75}$ See United Steelworkers v. Weber, 99 S. Ct. 2721, 2741-53 (Rehnquist J., dissenting); Yale Note, supra note 6, at 103 \& n.29. See generally Vaas, Title VII: Legislative History, 7 B.C. Indus. \& Com. L. REv. 431 (1966).

"See Developments in the Law-Employment Discrimination and Title VII of the Civil Rights Act of 1964, 84 HARv. L. Rev. 1109, 1113-19 (1971); Yale Note, supra note 6, at 104 \& n.32, 105. But see Note, Facially Neutral Criteria and Discrimination Under Title VI, supra note 7 , at 83 .

One commentator has argued that the Court in Griggs ignored the legislative history of Title VII, setting too strict a standard of job-relatedness, since Congress would have considered general aptitude and intelligence to be job related per se. Wilson, supra note 7, at 85258.

$\pi 110$ Cong. Rec. 7213 (1964). Accord, id. at 1540 (remarks of Rep. Lindsay); id. at 7711 (excerpting pro-Act group's pamphlet); $i d$. at 13,080 (remarks of Sen. Clark):

[An employer's complete freedom to choose his employees] is subject to one qualification, and that qualification is to state: "In your activity as an employer, . . . you must not discriminate because of the color of a man's skin. You may not discriminate on the basis of race, color, religion, national origin, or sex."

That is all this provision does.

7s Id. at 7213 . 
Opponents of Title VII were apparently unconvinced that its effect would be limited to bringing about equal treatment, for they predicted that the bill would lead to quota hiring and racial balancing by employers. ${ }^{79}$ Responding to these charges, supporters adamantly upheld the equal-treatment interpretation:

The language of . . . [Title VII] simply states that race is not a qualification for employment. Every man must be judged according to his ability. In that respect, all men are to have an equal opportunity to be considered for a particular job. . . .

... It is possible that although a . . particular business will contain no Negroes, no charge of discrimination will be made. But businesses . . . may not systematically exclude Negroes, when the only ground for exclusion is the color of a man's skin. ${ }^{80}$

When it amended Title VII in $1972,{ }^{81}$ Congress continued to adhere to an equal-treatment concept of discrimination. ${ }^{82}$ Representative Dent, the bill's floor manager in the House, remarked: "[N]o law can make men equal, but there has to be and there must be a law to give all men and women equal treatment." 83 " $\mathrm{He}$ also observed: "True justice has to be equal. That is what we are fighting for and what the blacks in this country are fighting for-equality of justice, equality of opportunity. They do not want special treatment . . . because special treatment itself breeds a sort of discrimination that you cannot tolerate."

7J E.g., id. at 1620 (remarks of Rep. Abernethy); id. at 6011, 8500 (remarks of Sen. Smathers); id. at 7422 (remarks of Sen. Robertson); id. at 8447 (remarks of Sen. Hill).

w Id. at 8921 (remarks of Sen. Williams). Accord, id. at 1994 (remarks of Rep. Healey); id. at 9881 (remarks of Sen. Allott); H.R. Rep. No. 914, 88th Cong., 1st Sess. 150 (1963), reprinted in EEOC, LEgislative HistoRY OF TTtLES VII AND XI OF Civil Rights ACT OF 1964, at 2150 (1968). See also Yale Note, supra note 6, at 106.

s) Equal Employment Opportunity Act of 1972, Pub. L. No. 92-261, 86 Stat. 103 (amending 42 U.S.C. $\$ \S 2000$ e to $2000 \mathrm{e}-17$ (1976)). See generally Sape \& Hart, Title VII Reconsidered: The Equal Employment Opportunity Act of 1972, 40 GEo. WASH. L. REv. 824 (1972).

82 The Section-by-Section Analysis of the 1972 amendments, submitted to each House by the Chairmen of the Conference Committee, implicitly approved Griggs (decided in 1971) by stating that existing court interpretations of Title VII continued to govern areas not covered by the amendments. 118 CoNG. REc. 7166, 7563 (1972).

s 117 Cong. Rec. 32,089 (1971) (remarks of Rep. Dent).

* Id. at 31,979 (remarks of Rep. Dent). Senator Ervin introduced two amendments expressly to prohibit government compulsion of quotas under Title VII or Exec. Order No. 11,246, 3 C.F.R. 339 (1964-1965 Compilation). 118 CoNG. REc. 1662-64, 4917-18 (1972). The defeat of these amendments, however, does not indicate any intention to expand the scope of, or alter the conceptual rationale for, liability under Title VII; rather, the Senate's apparent 
Proponents of Title VII also had to allay fears that the bill would be an intolerable encroachment on free enterprise. ${ }^{85}$ They repeatedly and consistently assured their colleagues that Title VII was only designed to deny employers the right to make employment decisions based on prohibited criteria, and that practices related to efficiency and productivity would not be restricted. An interpretative memorandum by Senator Case explained:

Whatever its merit as a socially desirable objective, title VII would not require, and no court could read title VII as requiring, an employer to lower or change the occupational qualifications he sets for his employees simply because proportionately fewer Negroes than whites are able to meet them. ... . [Nor would it require lower standards] because prior cultural or educational deprivation of Negroes prevented them from qualifying. ... .

Title VII says merely that a covered employer cannot refuse to hire someone simply because of his color. It expressly protects the employer's right to insist that any prospective applicant, Negro or white, must meet the applicable job qualifications. Indeed, the very purpose of title VII is to promote hiring on the basis of job qualifications, rather than on the basis of race or color. ${ }^{86}$

In the face of such direct statements, the only possible way to reconcile the rule of Griggs with the clear message of the legislative history is to conclude that Griggs cannot require any employer to "lower or change" his standards solely on account of their disparate impact on a protected group; a showing that those standards serve a legitimate business purpose must be a complete defense to a charge of disparate-impact discrimination.

concern was with maintenance of the courts' ability to devise proper remedies once liability was found. See id. at 1664-65, 4918 (remarks of Sens. Javits and Williams).

ss Especially troubling to the Congressmen was the decision of the Illinois Fair Employment Commission in Myart v. Motorola, Inc., Charge No. 63C-127 (1964), reprinted in 110 Cong. REc. 562-64 (1964), rev'd sub nom. Motorola, Inc. v. Illinois Fair Employment Practices Comm'n, 34 Ill. 2d 266, 215 N.E.2d 286 (1966), suggesting that no standardized test on which whites performed better than blacks could ever be used, even if justified by business necessity. See Griggs v. Duke Power Co., 401 U.S. 424, 434 n.10. Title VII's sponsors repeatedly disclaimed any such interpretation of the Act. E.g., 110 CoNG. Rec. $7246-47$ (1964) (memorandum of Sen. Case).

ss 110 Cong. REc. $7246-47$ (1964). Accord, id. at 1518 (remarks of Rep. Celler); id. at 7213 (memorandum of Sens. Clark and Case); id. at 13,079-80 (remarks of Sen. Clark); id. at 13,088 (remarks of Sen. Humphrey); id. at 13,825 (exchange of Sens. Case and McClellan). These statements of congressional intent were relied on heavily by the Griggs Court. 401 U.S. at $434 \&$ n.11. 


\section{B. Griggs's Interpretation of Legislative Intent}

The Griggs Court did not explicitly adopt any particular concept of discrimination and equality. Nevertheless, the language and reasoning of its opinion reveal that the Court's chief concern in interpreting and applying Title VII, consistent with the legislative materials just discussed, was not with achieving equal results for black and white employment, but with ensuring that employment opportunities be equally open to all applicants, free of arbitrary racial or race-related barriers. ${ }^{87}$ "Discriminatory preference for any group, minority or majority," the Court said, "is precisely and only what Congress has proscribed." 88

The Griggs Court seemed to apply a form of the functionalequivalence analysis when it discussed the relation between the disparate impact of Duke Power's employment criteria and the plaintiffs' race. It pointed out that the poorer performance of blacks on Duke Power's tests was "directly traceable to race," 89 resulting from low-quality segregated education. The Court noted that in an earlier case, "because of the inferior education received by Negroes in North Carolina, [it had] barred the institution of a literacy test for voter registration on the ground that the test would abridge the right to vote indirectly on account of race." Court apparently treated Duke Power's tests as unintentional surrogates for a direct racial criterion ${ }^{12}$-an approach consonant with Professor Fiss's functional-equivalence concept. ${ }^{92}$

The Court's discussion of the business necessity defense also leaves no implication that something more than a showing of a legitimate business purpose is required to avoid liability. ${ }^{93}$ The

${ }^{87}$ But see Note, Facially Neutral Criteria and Discrimination Under Title VI, supra note 7 , at 105.

is 401 U.S. at 431 (emphasis added).

"Id. at 430 .

10 Id. (emphasis added) (citing Gaston County v. United States, 395 U.S. 285 (1969)).

"The Court said that Title VII prohibits "artificial, arbitrary, and unnecessary" criteria that "operate invidiously to discriminate." 401 U.S. at 431 . It likened such criteria to Aesop's fable in which a fox invited a stork to dine and served the meal in a low, flat dish. The unfairness in this is manifest: although both animals were served the same food in the same dish, the stork was in fact not served. The Court said that Congress has required "that the vessel in which the milk is proffered be one all seekers can use." Id. See also Regents of Univ. of Cal. v. Bakke, 438 U.S. 265, 308 n.44 (1978) (opinion of Powell, J.) (dictum): "[T] he presumption in Griggs . . . was based on legislative determinations . . . that past discrimination had handicapped various minority groups to such an extent that disparate impact could be traced to identifiable instances of past discrimination . . . ."

22 See text and notes at notes 62-68 supra.

${ }^{93}$ Cf. Furnco Constr. Corp. v. Waters, 438 U.S. 567 (1978) (legitimate business purpose rebuts prima facie showing of "disparate treatment" discrimination under McDonnell Doug- 
Court stressed that Congress intended to make job qualifications "the controlling factor" in employment considerations and to make "race, religion, nationality, and sex . . . irrelevant." Tests that reasonably measure job performance are permitted even if they have a disparate impact, since they advance this goal. ${ }^{95}$

C. The Subsequent Supreme Court Interpretations

The Court has never explicitly stated what general rationale underlies its decision in Griggs. Yet in subsequent Title VII cases, the Court has consistently held that Title VII only requires an employer to accord equal treatment to individuals. In a recent case, however, the Court held that Title VII does not forbid employers to adopt voluntarily a plan that gives a preference to blacks as a class. ${ }^{96}$

The Court's most direct treatment of the individual/class equality issue is found in City of Los Angeles $v$. Manhart. ${ }^{97}$ The case involved a class action challenging the pension plan of the city's Department of Water and Power. The plan required female employees to make larger contributions than male employees. The basis for the differential was the unchallenged actuarial fact that the female employees, on the average, would live a few years longer than the males; since monthly pension payments were the same for each sex, the cost of a pension was greater for female retirees than for male retirees. ${ }^{98}$ Justice Stevens, writing for the Court, framed the resultant issue squarely: "The question . . . is whether the existence or nonexistence of 'discrimination' is to be determined by comparison of class characteristics or individual characteristics." 99

Justice Stevens found no room for doubt in the language of Title VII: in unambiguous terms it prohibits discrimination

las Corp. v. Green, 411 U.S. 792 (1973)); TWA v. Hardison, 432 U.S. 63, 84 (1977) (employer not required by Title VII's religious discrimination provision, section 703(a)(1), 42 U.S.C. $\S 2000 \mathrm{e}-2(\mathrm{a})(1)(1976)$, to incur more than "de minimis cost" to accommodate employee's religious needs).

" 401 U.S. at 436.

${ }^{25}$ Id. For support, the Court quoted an interpretative memorandum by Senator Case, a floor manager of Title VII: "Title VII 'expressly protects the employer's right to insist that any prospective applicant, Negro or white, must meet the applicable job qualifications. Indeed, the very purpose of Title VII is to promote hiring on the basis of qualifications, rather than on the basis of race or color." " 401 U.S. at 434 (quoting 110 CoNG. REc. 7247 (1964)) (emphasis added by the Court). The Court mistakenly ascribed co-authorship of the memorandum to Senator Clark.

${ }^{8 B}$ United Steelworkers v. Weber, 99 S. Ct. 2721 (1979); see text and notes at notes 108-

115 infra.

${ }^{77} 435$ U.S. 702 (1978).

${ }^{88} \mathrm{Id}$. at 704-05.

"Id. at 708. 
"'against any individual . . . because of such individual's race, color, religion, sex, or national origin.' "100 Hence, even an accurate generalization cannot be used against individuals whom it does not fit; they must be treated as individuals, not as class members. Justice Stevens went on to state that the "basic policy" of Title VII is "fairness to individuals rather than fairness to classes."

In International Brotherhood of Teamsters $v$. United States, ${ }^{102}$ the Court again interpreted Title VII as protecting individuals and not classes. The district court, after finding that the employer's seniority system unlawfully prevented the plaintiff class from transferring to more desirable positions within the company, ordered that the injured plaintiffs receive priority in job placement and retroactive seniority. ${ }^{103}$ The court of appeals adjusted the district court's remedy but still extended relief to all minority employees. ${ }^{104}$ The Supreme Court reversed, holding that the only employees entitled to relief were those who could show that they had applied for a transfer or would have applied but for the company's seniority system. Title VII, the Court held, protects only individual victims of discrimination and not all of the company's minority employees as a class. ${ }^{105}$

There is also dictum in Regents of the University of California v. Bakke ${ }^{108}$ supporting this interpretation of Title VII. Justice Stevens, joined by Chief Justice Burger and Justices Stewart and Rehnquist, stated that Congress believed Title VII embodied "the

100 Id. at 708 (quoting 42 U.S.C. $\$ 2000 \mathrm{e}-2(a)(1)$ (1976)) (emphasis added by the Court).

Iot 435 U.S. at 709. Although only three Justices (Stewart, White, and Powell) joined in all of Justice Stevens's opinion, it is apparent that at least seven of the eight participating Justices agreed with Justice Stevens that Title VII is directed toward fairness to individuals rather than classes. Justice Marshall joined in the relevant part of the Court's opinion, dissenting only from the holding on relief, $i d$. at 728-33. Chief Justice Burger and Justice Rehnquist, by contrast, concurred on the relief point but dissented as to Title VII liability, id. at 725-28. Although they agreed that Title VII mandates fair treatment as between individuals, id. at 727-28 (by implication), they concluded that the Department of Water and Power had done as much as possible. Justice Blackmun concurred in the judgment, but expressed doubts as to the liability holding, id. at 723-25; his attitude toward the larger issue does not emerge. Justice Brennan did not participate.

102431 U.S. 324 (1977).

${ }^{103}$ United States v. T.I.M.E.-DC, Inc., 6 Fair Empl. Prac. Cas. 690 (N.D. Tex. 1972), modified, 517 F.2d 299 (5th Cir. 1975), vacated and remanded sub nom. International Bhd. of Teamsters v. United States, 431 U.S. 324 (1977).

104517 F.2d 299 (5th Cir. 1975), vacated and remanded sub nom. International Bhd. of Teamsters v. United States, 431 U.S. 324 (1977).

105431 U.S. at $362-71$.

106438 U.S. 265 (1978). 


\section{principle of individual equality."107}

The only case that casts some doubt on this interpretation of Title VII is United Steelworkers $v$. Weber. ${ }^{108}$ There the Court held that the Kaiser Aluminum Company's affirmative action plan was permissible under Title VII. Although the Court found a raceconscious employment practice legal and emphasized Congress's desire, in enacting Title VII, to improve the position of blacks as a class, ${ }^{109}$ it strictly limited its holding to plans that are voluntarily and privately operated. The Court did not address what "Title VII requires or ... what a court might order ... [but only] whether Title VII forbids private employers and unions from voluntarily agreeing upon bona fide affirmative action plans." 110

. The narrowness of the Court's holding in Weber is highlighted by its approving reference to McDonald $v$. Santa Fe Trail Transportation Co. ${ }^{11}$ In that case, two white employees were dismissed after being charged with misappropriating a shipper's goods. A black employee, charged in the same alleged theft, was retained. The whites sued, alleging a discriminatory discharge in violation of Title VII and section 1981 of Title $42 . .^{112}$ The Court unanimously ${ }^{113}$ held that Title VII bars racial discrimination against whites as well as against blacks and other members of disadvantaged racial groups. ${ }^{114}$ The Weber Court distinguished McDonald on the basis that Weber

${ }^{107} \mathrm{Id}$. at 416 n.19 (Stevens, J., concurring in part, dissenting in part) (emphasis in original).

${ }^{103} 99$ S. Ct. 2721 (1979).

${ }^{109}$ The Weber majority purported to rest this conclusion on several quotations taken from Senate debates on Title VII. See id. at 2727-28. Most of the quoted passages, however, lend themselves as easily to an equal-treatment interpretation of Title VII as to an equalachievement theory. Senator Humphrey, for example, is quoted as making the following point: " "How can a Negro child be motivated to take full advantage of integrated educational facilities if he has no hope of getting a job where he can use that education?' "Id. at 2727 (quoting 110 CoNG. REc. 6547 (1964)). It does not follow, however, from Senator Humphrey's statement that minorities should be assured good jobs; it may simply mean that minorities should not be shut out of jobs on account of race. See 110 CoNG. REC. 5423, 6549, 6553, 11,848 (1964) (remarks of Sen. Humphrey) (supporting equal-treatment interpretation of Title VII, and stating that the Title prohibits minority preference). Justice Rehnquist, dissenting, analyzed the legislative history and concluded that the majority's construction of Title VII was a misinterpretation of congressional intent of Orwellian dimensions. $99 \mathrm{~S}$. Ct. at 2736 . 37, 2747-52. This view was also shared by Chief Justice Burger, id. at 2736 (Burger, C.J., joining Rehnquist, J., dissenting), and by Justice Blackmun, id. at 2730-31, 2732 (Blackmun, J., concurring). Hence since Justices Powell and Stevens did not participate in the decision, the majority's view of the legislative history was shared by only four Justices.

11099 S.Ct. at 2726 (emphasis in original).

11i 427 U.S. 273 (1976).

11242 U.S.C. \& 1981 (1976).

113 Justices White and Rehnquist dissented in part on other grounds.

us 427 U.S. at $278-80$. 
involved an affirmative action plan while $M c D$ onald involved plain racial discrimination. ${ }^{115}$ Weber thus seems to leave undisturbed those cases holding that Title VII requires employers to provide equal treatment regardless of race.

\section{The Proper Scope of the Business Necessity Defense}

The theoretical underpinnings of the business necessity defense, the legislative history of Title VII, and the Supreme Court's interpretations of that history all suggest that business necessity means nothing more than legitimate business purpose. The higher standard of business necessity adopted by the lower courts ${ }^{116}$ is fundamentally inconsistent with the equal-treatment rationale of the Act.

The lower courts have relied on a textual distinction between "business purpose" and "business necessity"; many of these courts have concluded that, by using the term "necessity," the Griggs Court erected a standard higher than mere business purpose. ${ }^{117} \mathrm{Such}$ an interpretation of Griggs places unwarranted reliance on a single phrase in the opinion. The Court made several references to the defense, using (apparently interchangeably) the phrases "business necessity,"118 "genuine business need,"119 "manifest relationship to the employment," 120 "demonstrable relationship to successful performance of the jobs,"121 "reasonable measure of job performance,"122 "related to job performance,"123 and "job related."124 Plainly, the Court did not intend to give any special meaning to the word "necessity." Reading special significance into the term "necessity" does not comport with the clear tenor of the opinion.

The Griggs Court, indeed, never stated that Title VII would forbid an employer from using the objectively best available criteria

11399 S. Ct. at 2726-27 (citing McDonald, 427 U.S. at $281 \mathrm{n} .8$ ).

i's See text and notes at notes 6-7, 41, 45-55 supra.

"17 See, e.g., Green v. Missouri Pac. R.R., 523 F.2d 1290, 1298 (8th Cir. 1975) (business necessity " 'connotes an irresistible demand' "); United States v. Bethlehem Steel Corp., 446 F.2d 652, 662 (2d Cir. 1971) (same). But see Blake v. City of Los Angeles, 595 F.2d 1367, 1376 (9th Cir. 1979), where the court quoted dictum in a footnote in Dothard v. Rawlinson, 433 U.S. 321, 332 n.14 (1977), to reach its conclusion that an "employment practice must be shown to be necessary to safe and efficient job performance." "

118401 U.S. at 431.

1" Id. at 432 .

$120 \mathrm{Id}$.

${ }^{121}$ Id. at 431.

122 Id. at 436.

123 Id. at 431.

12 Id. at 436. 
for predicting job performance. On the contrary, the Court strongly suggested that employers must use precisely those standards: "Congress has not commanded that the less qualified be preferred over the better qualified simply because of minority origins. Far from disparaging job qualifications as such, Congress has made such qualifications the controlling factor, so that race, religion, nationality, and sex become irrelevant." 25 The holding in Griggs simply prevents employers from using uneconomic criteria-criteria unrelated to job performance-that decrease minority opportunities.

A better explanation for the Court's reference to "necessity" rather than "purpose" emerges if one considers the term in the context of the holding of Griggs that race-correlative employment criteria must be shown to be job related. The term serves to make it clear that the standard of job-relatedness is an objective one. If an employer believes that his employment practices serve his business needs, his purpose in applying them is a "business purpose," whether or not his belief is factually correct. But only if the practice in fact serves business purposes can it be deemed "necessary" to the firm's efficient operation.

\section{ConcLuston}

Griggs v. Duke Power Co. has been called "the most important court decision in employment discrimination law." ${ }^{26}$ As a seminal case, it has given rise to numerous lower court opinions interpreting and applying its holding. But with respect to the scope of the business necessity defense, the lower courts have departed from the teachings of Griggs and the legislative history of Title VII-a departure attributable to a failure to appreciate the theory underlying disparate-impact liability. An examination of this theory shows that the Griggs theory of Title VII is properly explained by Professor Fiss's "functional equivalence" approach to racial discrimination, and that this approach implies a far more generous standard of business necessity than the lower courts have allowed.

Marcus B. Chandler

${ }^{125} \mathrm{Id}$.

12s B. Schlei \& P. Grossman, supra note 3 , at 5 (footnote omitted). 